Endocrinol. Japon. 1978, 25 (1), 19-26

\title{
Effects of TRH on Circulating Growth Hormone, Prolactin and Triiodothyronine Levels in the Bovine
}

\author{
Tetsu JOHKE \\ Department of Physiology, National Institute of Animal \\ Industry, Chiba-shi 280, Japan
}

\begin{abstract}
Synopsis
The effects of administration of synthetic thyrotropin-releasing hormone (TRH) on circulating growth hormone $(\mathrm{GH})$, prolactin $(\mathrm{PRL})$ and triiodothyronine $\left(\mathrm{T}_{3}\right)$ levels of lactating dairy cows, non-lactating dairy heifers, and beef cows were studied. Intravenous administration of $0.1,1$, and $5 \mu \mathrm{g}$ of $\mathrm{TRH}$ per $\mathrm{kg}$ of body weight (bw) elevated plasma GH and PRL levels of lactating cows within $5 \mathrm{~min}$. The plasma GH and PRL levels increased in proportion to the dose of TRH and reached a peak 10 to $30 \mathrm{~min}$ after TRH injection. Intravenous administration of $1 \mu \mathrm{g}$ of TRH per $\mathrm{kg}$ of bw to 7 non-lactating heifers, 14 lactating dairy cows, and 5 non-lactating beef cows elevated plasma GH level to peak values after $15 \mathrm{~min}$, the increase rates being 6.9, 5.6, and 3.8 times as high as those in the pretreatment levels. The mean maximum value was also in that order. Plasma $T_{3}$ levels of non-lactating dairy heifers at pre- and post-injection of TRH were significantly higher than those of lactating cows. The peak values of plasma PRL were obtained between 5 to 30 min after TRH administration. The increase rates of lactating dairy cows, heifers, and beef cows were 19.2, 13.9, and 20.9 times as high as those in the pretreatment. In contrast to GH and $\mathrm{T}_{3}$, plasma PRL levels of both pre- and post-injection with TRH in lactating cows and heifers were significantly higher in May than in October, though the increase rates were similar. Plasma PRL levels of lactating dairy cows at pre- and post-injection with TRH were significantly higher than those of non-lactating heifers. Subcutaneous administration of TRH was also effective to increase plasma GH, PRL, and $\mathrm{T}_{3}$ levels in lactating cows. No significant change of GH or PRL response to TRH was observed after a short-term pretreatment of thyroid hormones.
\end{abstract}

Thyrotropin-releasing hormone (TRH) causes the release of thyrotropin (TSH) from pituitaries of several species (Blackwell and Guillemin, 1973). Furthermore, it has been shown that the administration of synthetic TRH stimulates PRL secretion of humans (Bowers et al., 1971; Jacobs et al., 1973), cattle (Schams, 1972; Convey et al., 1973; Kelly et al., 1973; Johke, 1973; Vines et al., 1976), sheep (Debeljuk et al., 1973; Fell et al., 1973) goats (Johke, 1973; McMutrry and Malven, 1974) and rats (Mueller et al.,

Received June 29, 1977.
1973; Blake, 1974). Exogenous TRH also stimulated GH secretion in cattle (Convey et al., 1973; Johke and Hodate, 1974; Vines et al., 1976), anesthetized rats (Takahara et al., 1974; Kato et al., 1975), and human in acromegaly (Irie and Tsushima, 1972) or mental depression (Maeda et al., 1975), but did not normal subjects.

In the present experiments, the effect of synthetic TRH on GH, PRL, and $\mathrm{T}_{3}$ releases in lactating dairy cows, non-lactating dairy heifers, and beef cows was studied with radioimmunoassays. In considering the differences of body weight (bw) of ex- 
perimental animals, a constant amount of TRH per $\mathrm{kg}$ of bw was given to the animals.

\section{Materials and Methods}

\section{Experimental animals}

Twenty-six lactating Holstein dairy cows in the middle stage of lactation, $590-670 \mathrm{~kg}$ in bw, 4 to 8 years of age, 7 non-lactating Holstein dairy heifers, 350 to $370 \mathrm{~kg}$ in bw, 13 to 16 months of age, 5 Japanese Shorthorn beef cows, 410 to $530 \mathrm{~kg}$ in bw, 2-3 years of age from the Institute herd were used. The cattle were on pastures or paddocks except at feeding and milking twice a day. The experiments were carried out in late May and early October in 1973. The mean ambient temperature and daylight length in late May during the experiments were $18^{\circ} \mathrm{C}$ and $13.6 \mathrm{hr}$. The values in early October were $19.7^{\circ} \mathrm{C}$ and $11.8 \mathrm{hr}$, respectively.

\section{Blood sampling method}

The blood of the experimental animals was taken from an indwelling catheter inserted into one of the external jugular veins. The blood samples were collected before, and during 2 to $3 \mathrm{hr}$ after TRH injection. Serial 5 or $10 \mathrm{ml}$ of bood samples were collected into centrifuge tubes containing heparin, and immediately chilled with ice. The blood was centrifuged and the plasma was stored at $-20^{\circ} \mathrm{C}$ until assay.

\section{Effect of TRH dose}

In May, $0.1,1$, and $5 \mu \mathrm{g}$ of synthetic TRH (Tanabe Pharmaceutical Co. Ltd., Osaka) per $\mathrm{kg}$ of bw was given intravenously (iv) to 2 lactating cows.

Responses in lactating dairy cows, non-lactating dairy heifers and non-lactating beef cows

In May, 7 lactating dairy cows, 4 non-lactating dairy heifers and 4 beef cows were administered iv with $1 \mu \mathrm{g}$ of TRH. In the lactating cows, TRH was given $4 \mathrm{hr}$ after morning milking. In October, 7 lactating dairy cows, 3 non-lactating dairy heifers and a beef cow were injected iv with $1 \mu \mathrm{g}$ of TRH per $\mathrm{kg}$ of bw. The animals received the same additional dose of TRH $125 \mathrm{~min}$ after the first treatment.

\section{Route of administration}

Two mg of TRH was injected subcutaneously (sc) to 2 lactating cows in October.

\section{Effect of thyroid hormones pretreatment}

An alkaline saline solution of $9 \mathrm{mg}$ thyroxine $\left(T_{4}\right)$ and $6 \mathrm{mg} \mathrm{T}_{3}$ (Sigma Co. Ltd.) was injected sc 3, 20, and $26 \mathrm{hr}$ before TRH administration in May. The plasma GH and PRL values were compared with those obtained in the experiment which was carried out 7 days before without thyroid hormones pretreatment.

\section{Radioimmunoassay for hormones}

Growth hormone: Antisera to bovine growth hormone (bGH) were prepared in 2 monkeys (crab eating macaque) by repeated sc injections of bGH emulsified with Freund's complete adjuvant. Antisera to bGH were absorbed with bovine PRL and serum. A highly purified bGH preparation kindly supplied by Professor C. H. Li, University of California, was iodinated with the chloramine $\mathrm{T}$ method as in the case of bPRL (Johke, 1969). To $1.0-1.5 \mathrm{mCi}$ of $\mathrm{Na}^{125}$ I (New England Nuclear, Cambridge, Mass., U.S.A.) were added $30 \mu l$ of $0.5 \mathrm{M}$ phosphate buffer, $\mathrm{pH} 7.5,20 \mu \mathrm{g}$ of chloramine $\mathrm{T}$, and $5 \mu \mathrm{g}$ of bGH in $25 \mu l$ in that order. Radioiodinated GH was separated by $1 \times 15 \mathrm{~cm}$ Sephadex G75 column equilibrated with $0.05 \mathrm{M}$ barbital buffer, $\mathrm{pH}$ 8.6. The labelled GH was used for the assay within $24 \mathrm{hr}$ after radioiodination.

Free ${ }^{125} \mathrm{I}$-bGH from antibody-bound ${ }^{125} \mathrm{I}$-bGH was separated by the double antibody method. The diluent consisted of $2 \%$ bovine serum albumin (BSA) in $0.05 \mathrm{M}$ barbital buffer, $\mathrm{pH} 8.6$, containing $0.01 \mathrm{M}$ EDTA and $0.01 \%$ merthiolate. In routine assays, the reagents were added to each tube $(10 \times 75 \mathrm{~mm})$ following order and mixed throughly by a micromixer. To 0.6 to $0.68 \mathrm{~m} l$ of diluent was added the standard hormone or the assay sample $(0.02-0.1 \mathrm{ml})$ and $0.1 \mathrm{~m} l$ of monkey antiserum to bGH $(1: 20000)$ containing $0.5 \%$ normal monkey serum. After an incubation for 2 days at $4^{\circ} \mathrm{C}, 0.1 \mathrm{ml}$ of antiserum to MGG (1:12) was added. After re-incubation at $4^{\circ} \mathrm{C}$ for another $24 \mathrm{hr}$, the reaction mixtures were centrifuged at $3000 \mathrm{rpm}$ for $20 \mathrm{~min}$ at $4^{\circ} \mathrm{C}$ and the supernatants were discarded by decantation. The percent radioactivity of the precipitate was calculated by counting the precipitate using an automatic gamma counter (Nuclear Chicago 4218). BGH and other pituitary hormones for standards were generously supplied by the National Institute of Arthritis, Metabolism and Digestive Diseases, U.S.A. A bovine GH preparation (NIH-GH-B12) was used as the standard hormone in the assay.

In the homologous radioimmunoassay for bGH, bovine plasma and pituitary extract inhibited the reaction between ${ }^{125} \mathrm{I} \cdot \mathrm{bGH}$ and the antibody to $\mathrm{GH}$ in the same way as the standard bGH (NIH-GH-B12) or ovine GH (NIH-GH-S9). Caprine plasma inhibited the reaction identically with the purified ovine $\mathrm{GH}$ or bGH. Therefore, determination of bovine, ovine, and caprine $\mathrm{GH}$ can be made by bovine or ovine $\mathrm{GH}$ as the standard hormone. Bovine PRL (NIHP-B2), LH (LER-1716-2), TSH (NIH-TSH-B2) and 
ovine FSH (NIH-FSH-S3) up to $100 \mathrm{ng}$ did not show any significant change in the percentage of antibodybound ${ }^{125} \mathrm{I}-\mathrm{bGH}$. The coefficient of variation within assay was $7 \%(n=5)$, and that between assay was $11 \%(\mathrm{n}=5)$. The maximum sensitivity was $1 \mathrm{ng} / \mathrm{m} l$ of plasma or serum. The mean recovery of added bGH to bovine plasma was $106 \%$. No difference was observed in $\mathrm{GH}$ concentration of plasma or serum from the same blood sample. There was no significant decrease of immunoreactive $\mathrm{GH}$ concentration during the storage for a year at $-20^{\circ} \mathrm{C}$.

Prolactin: Plasma PRL was determined by a slightly modified method of Johke (1969). To minimize pipetting, an antiserum to PRL was diluted with a diluent containing $0.5 \%$ normal guinea pig serum. The diluent was $0.05 \mathrm{M}$ barbital buffer, $\mathrm{pH} 8.6$, containing $1 \%$ BSA, $0.01 \mathrm{M}$ EDTA, and $0.01 \%$ merthiolate. Diluted or undiluted 20 to $100 \mu l$ of plasma was added to reaction tubes. The final reaction volume was adjusted to $1 \mathrm{ml}$ by adding diluent.

Triiodothyronine: Plasma $\mathrm{T}_{3}$ was estimated by $\mathrm{T}_{3}$ radioimmunoassay kits (Dainabot Radioisotope Laboratory). Free and antibody-bound $\mathrm{T}_{3}$ were separated by the dextran-coated charcoal method.

\section{Results}

\section{Effect of dose of TRH}

Intravenous injection of $0.1,1$, and $5 \mu \mathrm{g}$ of TRH per $\mathrm{kg}$ of bw caused a significant increase in plasma GH and PRL concentrations within 5 min (Fig. 1). The peak plasma GH level was obtained 10 to 15 min after TRH administration. In the case of PRL, the peak value was observed 30 min after TRH injection. The peak values of GH and PRL increased proportionally to the dose of TRH injected. Plasma $\mathrm{T}_{3}$ level showed a gradient increase after TRH injection. However, the responses were not related to the dose. Saline injection did not result in significant changes of plasma GH and PRL concentrations.
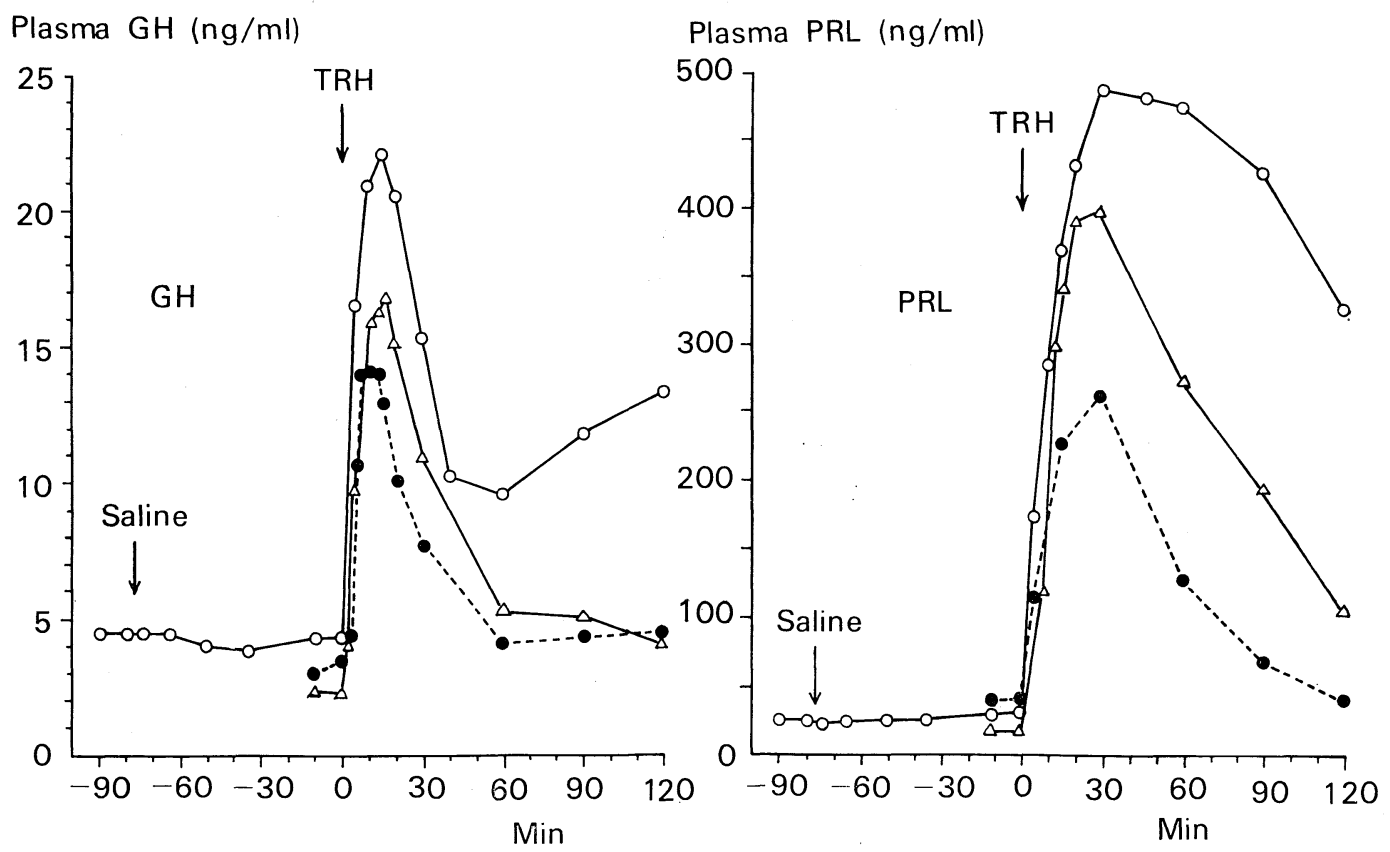

Fig. 1. Mean plasma GH and PRL responses in two lactating cows iv administered $0.1(O), 1.0(\triangle)$, and $5 \mu \mathrm{g}(\bigcirc)$ of synthetic TRH per $\mathrm{kg}$ of bw at time 0 . The peak values of GH and PRL increased proportionally to the dose of TRH. Saline injection did not change plasma GH and PRL concentrations. 
Responses in lactating dairy cows, nonlactating dairy heifers and beef cows

Plasma GH concentrations of 14 lactating Holstein dairy cows, 7 non-lactating Holstein dairy heifers, and 5 Shorthorn beef cows rose to a maximum after 15 min following the iv injection of $1 \mu \mathrm{g}$ of TRH per $\mathrm{kg}$ of bw. No significant differences of the basal and peak plasma GH levels between May and October were observed. Therefore, the data were combined. The maximum plasma $\mathrm{GH}$ levels in dairy heifers, lactating dairy cows, and beef cows were $6.9(\mathrm{p}<0.005), 5.6(\mathrm{p}<$

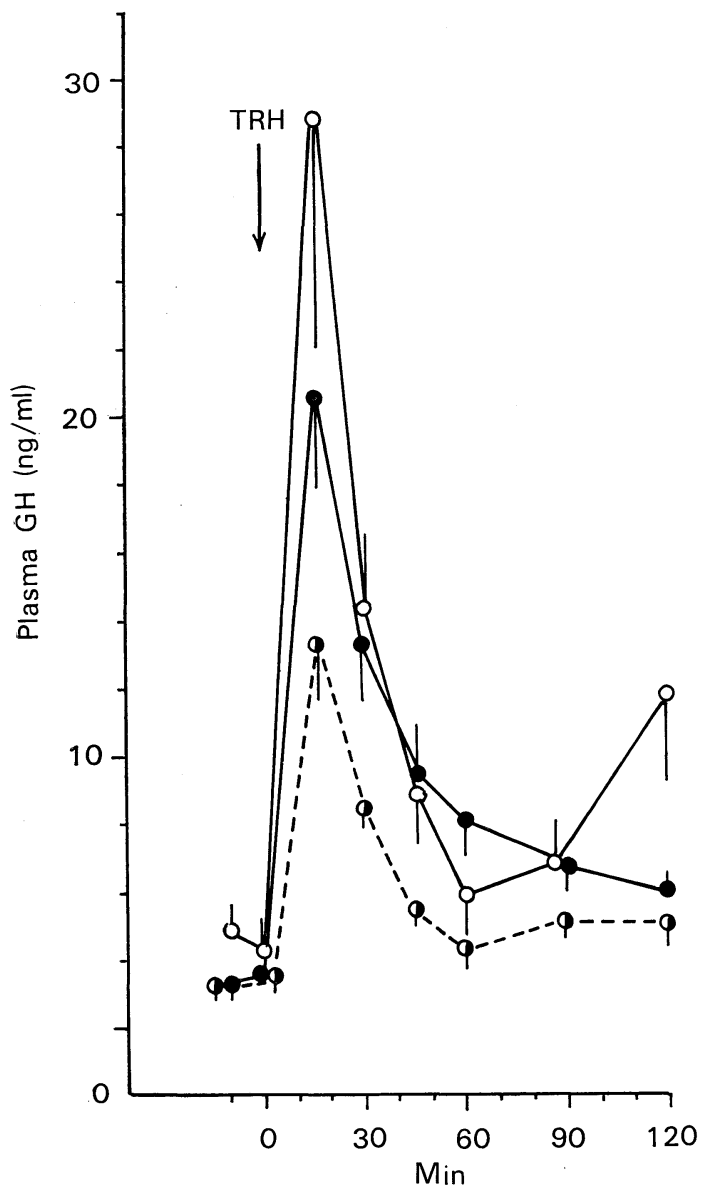

Fig. 2. Plasma GH responses to iv administration of $1 \mu \mathrm{g}$ of TRH per $\mathrm{kg}$ of bw in non-lactating dairy heifers (O), 14 lactating dairy cows (O), and 5 non-lactating beef cows ( $)$. Mean \pm SE.
$0.001)$, and $3.8(\mathrm{p}<0.005)$ times as high as the basal levels, respectively (Fig. 2). The mean peak plasma GH level after TRH was higher in non-lactating dairy heifers, lactating cows, and beef cows in that order, though the differences were not statistically significant. The second peak GH levels after the additional TRH injection in non-lactating dairy heifers and lactating cows were 77 and $76.3 \%$ of the first peak values.

Differences of the basal and elevated levels of plasma $T_{3}$ were not observed between May and October. In the combined data, the plasma $T_{3}$ level of lactating dairy cows, heifers and beef cows were $1.40(\mathrm{p}<$ $0.005), 1.38 \quad(\mathrm{p}<0.0025)$ and 1.61 times $(\mathrm{p}<0.001)$ as high as the pretreatment level $2 \mathrm{hr}$ after TRH injection (Fig. 3). The preand post-TRH injection levels of plasma $T_{3}$ in non-lactating dairy heifers were significantly higher than those of lactating dairy cows $(\mathrm{p}<0.05)$.

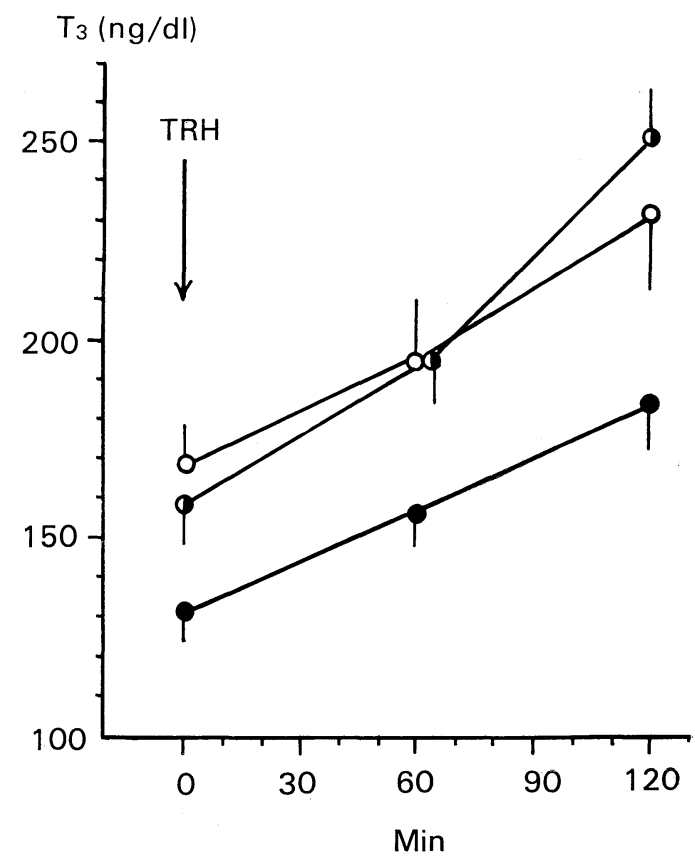

Fig. 3. Plasma $T_{3}$ responses to iv admimistration of $1 \mu \mathrm{g}$ of TRH per $\mathrm{kg}$ of bw in 7 non-lactating dairy heifers $(O), 14$ lactating dairy cows $(O)$, and 5 non-lactating beef cows (O). Mean \pm SE. 
The mean plasma PRL level of lactating cows rose to a maximum at $30 \mathrm{~min}$ following the iv injection of $1 \mu \mathrm{g}$ of TRH per $\mathrm{kg}$. The mean peak value of non-lactating dairy heifers and beef cows was observed 5 and $15 \mathrm{~min}$ after TRH administration, respectively (Fig. 4). The maximum plasma PRL levels in lactating dairy cows, non-lactating heifers and beef cows in May were 19.2, 13.9, and 20.9 times as high as the pretreatment level, respectively. In contrast to $\mathrm{GH}$ and $\mathrm{T}_{3}$, plasma PRL levels of pre- and post-injection of TRH were significantly different in May and October, though the increase rates were similar (Fig. 4). The basal and maximum PRL levels of the lactating cows in May were $1.9-(\mathrm{p}<0.05)$ and 2.6 -folds $(\mathrm{p}<0.005)$ higher than those in October. In the heifers, the basal and maximum PRL levels in May were $3.7-(p<0.01)$ and 3.0 -folds $(p<0.05)$ higher than those in October. The mean maximum PRL level in the lactating cows was 1.9 times in May and 2.5 times in October to that of heifers. On the other hand, the mean of maximum plasma PRL level of the beef cows was higher than that of the dairy heifers in May. The 2 nd peak PRL levels after the additional TRH injection in lactating dairy cows and nonlactating heifers were 73.8 and $51.8 \%$ of the first peak values (Fig. 4).

The mean plasma $\mathrm{GH}$ concentration immediately after venipuncture $(3.4 \pm 0.3$ $\mathrm{ng} / m l, \mathrm{SE})$ was not significantly different from the basal value $(3.7 \pm 0.4 \mathrm{ng} / \mathrm{ml})$ in 14 lactating cows. In contrast, the mean plasma PRL level immediately after venipuncture $(30.4 \pm 2.4 \mathrm{ng} / \mathrm{ml})$ was significantly

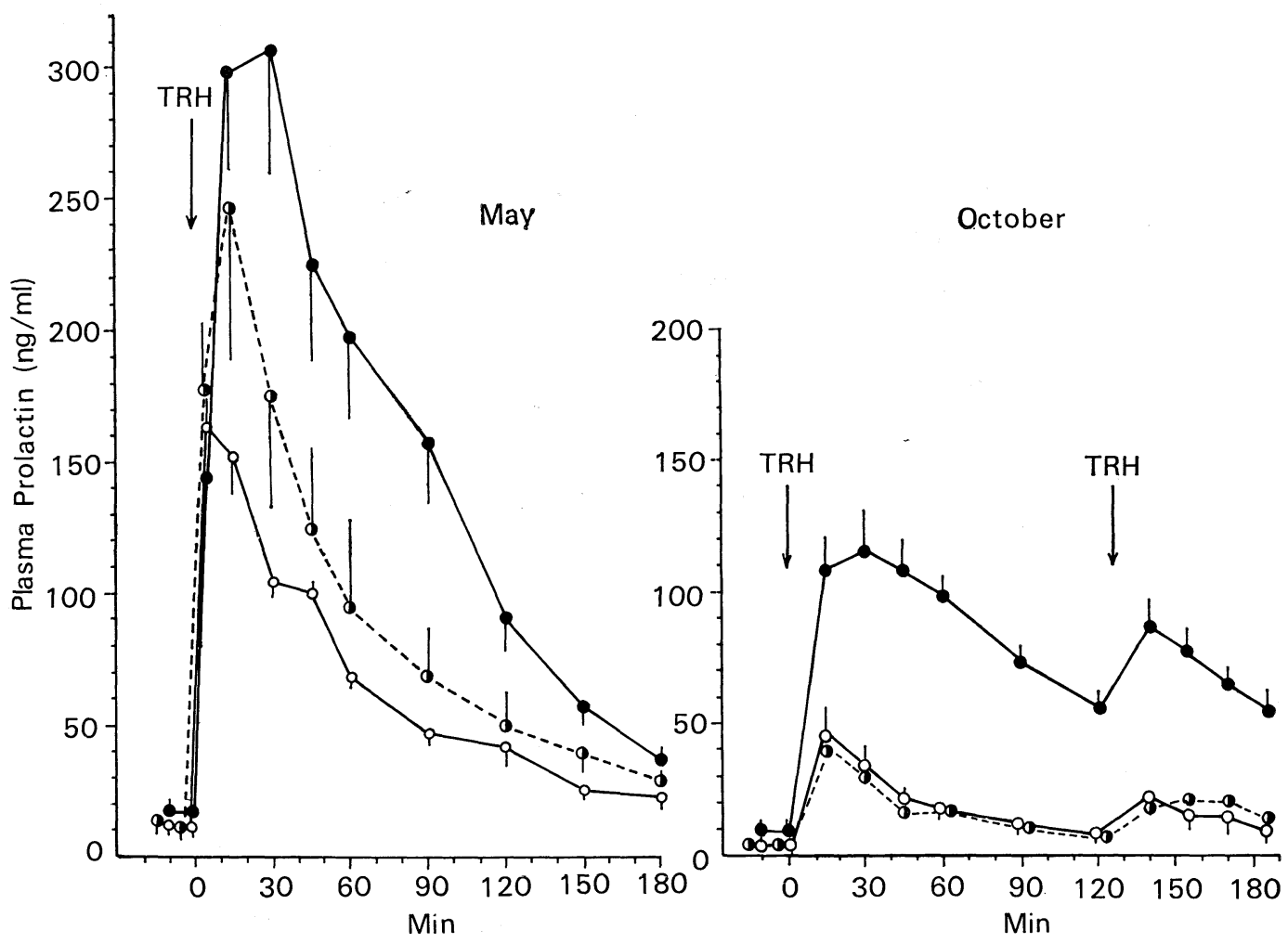

Fig. 4. Plasma PRL responses to iv administration of $\mathrm{TRH}(1 \mu \mathrm{g}$ per $\mathrm{kg}$ of bw) in lactating dairy cows (O), non-lactating dairy heifers $(\bigcirc)$, and non-lactating beef cows $(\boldsymbol{D})$ in May and October. An additional TRH injection was given 125 min after the first treatment. Mean \pm SE. 
higher $(\mathrm{p}<0.05)$ than the basal level $(20.8 \pm 3.6 \mathrm{ng} / \mathrm{ml})$. Similar results were also obtained in the non-lactating dairy heifers and the beef cows.

\section{Route of administration}

The subcutaneous injection of $2 \mathrm{mg}$ of TRH to lactating cows induced a prompt and conspicuous increase of plasma $\mathrm{GH}$, PRL, and also $T_{3}$ similarly to iv administration (Fig. 5).

\section{Effect of thyroid hormones pretreatment}

As shown in Fig. 6, a short-term pretreatment with thyroid hormones of lactating cows did not affect the responses of GH and PRL to TRH.

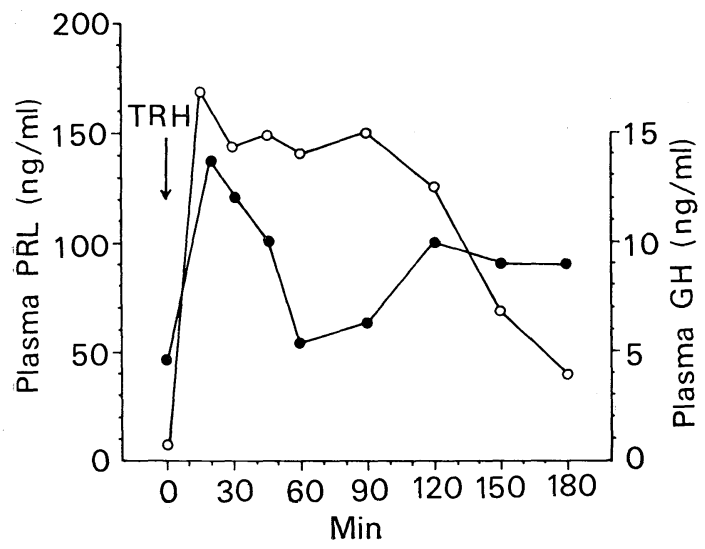

Fig. 5. Mean GH (O) and PRL (O) responses to sc injection of $2 \mathrm{mg} \mathrm{TRH}$ in two lactating cows in October.

\section{Discussion}

The intravenous administration of synthetic TRH to lactating and non-lactating cattle resulted in an immediate and marked increase of GH and PRL releases as well as elevation of plasma $T_{3}$ levels. Subcutaneous injection was also effective. In contrast to inconsistent bGH release to $\mathrm{TRH}$ in vitro

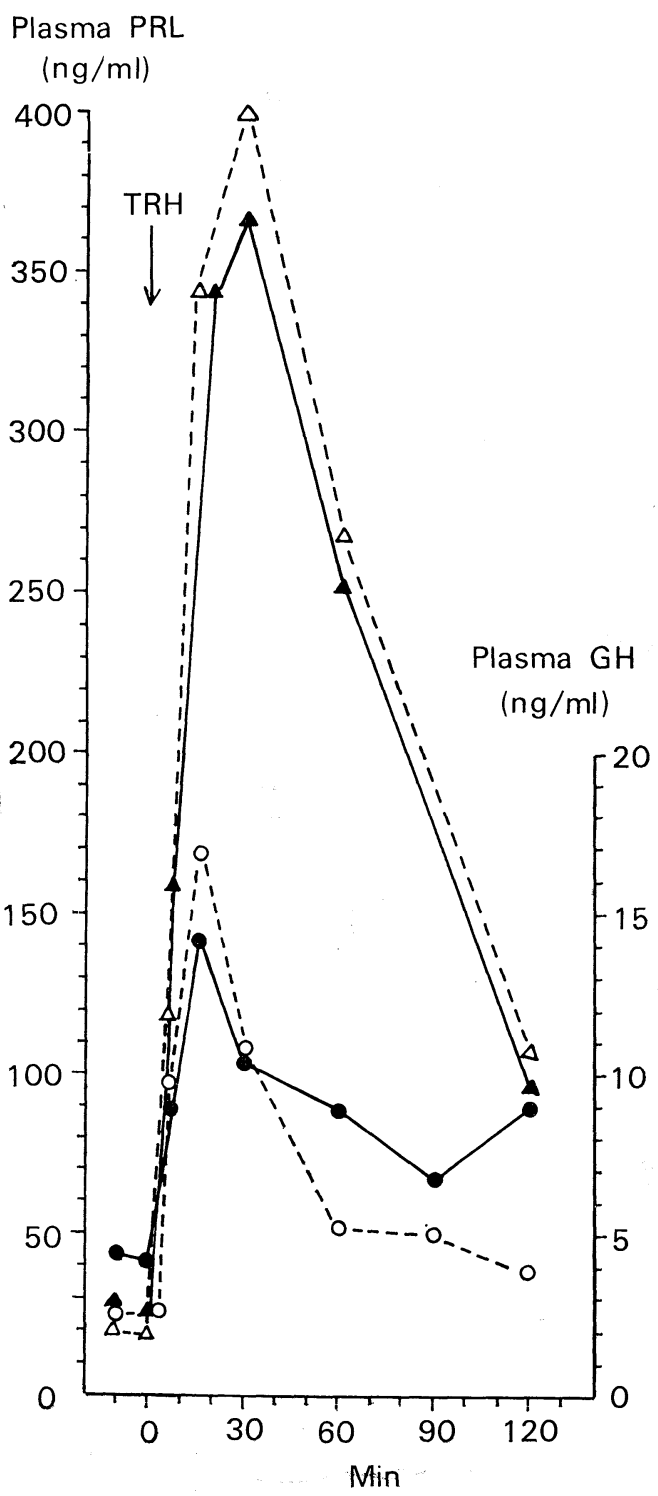

Fig. 6. Mean GH and PRL responses to TRH $(1 \mu \mathrm{g}$ per $\mathrm{kg} \mathrm{bw}$ ) in two lactating cows with and without a short-term thyroid hormones pretreatment. A mixture of $\mathrm{T}_{4}$ and $\mathrm{T}_{3}$ was injected sc, 3, 20, and $26 \mathrm{hr}$ before TRH administration in May. PRL ( $\Delta$ ), thyroid hormones pretreatment; PRL $(\triangle)$, control ; $\mathrm{GH}(\bigcirc)$ thyroid hormones pretreatment; GH (O), control. 
Labella and Vivian, 1971; Smith and Convey, 1975), a consistent elevation of plasma GH concentration was observed in vivo. The results agree with those in the previous reports on lactating cows (Convey et al., 1973) and heifers (Vines et al., 1976), in which 5-100 $\mu \mathrm{g}$ of TRH per animal was administered. In contrast to the previous studies (Convey et al., 1973; Kelly et al., 1973), the PRL response to TRH in lactating cows was proportional to the log dose of TRH. The result was similar to that reported in prepubertal heifers (Vines et al., 1976). The reason of the discrepancy is not known, but may be attributed to the difference of the dose of TRH employed. A constant dose of TRH per $\mathrm{kg}$ of bw instead of per animal, was administered in the present experiments.

The mean GH response to TRH in the dairy heifers or cows was higher than that in the beef cows. On the other hand, the mean PRL response to TRH in the beef cows in May was higher than that in the dairy heifers unexpectedly. The results suggest that dairy cattle may be superior in $\mathrm{GH}$ secretion to beef cattle, but may not be so in PRL secretion. Although the lactating cows received TRH administration $4 \mathrm{hr}$ after morning milking, the mean PRL response to $\mathrm{TRH}$ in the lactating cows was significantly higher than that in the heifers. On the other hand, plasma $T_{3}$ level in the dairy heifers was significantly higher than that in the lactating cows. Aged lactating cows tended to show lower plasma $\mathrm{T}_{3}$ concentration. The data suggest that age and lactatoin may affect plasma $T_{3}$ concentration.

In contrast to $\mathrm{GH}$ and $\mathrm{T}_{3}$, the basal and post-injection plasma PRL levels of lactating cows and heifers differed significantly in May and October, though the increase rate did not show a marked difference. A parallelism of variations of the bovine plasma PRL level and ambient temperature (Wettemann and Tucker, 1974; Johke, 1976; Tucker and Wettemann, 1976) or photoperiod (Bourne and Tucker, 1975; Johke, 1976) has been demonstrated. As in the case of response to milking stimulus (Koprowski and Tucker, 1973; Johke, 1974), the magnitude of the PRL release after TRH is affected by seasons. In the present study, the mean ambient temperature in early October was similar to that in late May. Accordingly, there is a possibility that the decrease in plasma PRL in October is mainly due to the effect of shortening the photoperiod. Bourne and Tucker (1975) found that the PRL secretion in bulls is more sensitive to the declining phase of photoperiod than the increasing phase.

In contrast to TSH (Hodate and Johke, 1977), a short-term pretreatment with thyroid hormones did not change $\mathrm{GH}$ and PRL responses to TRH in lactating cows. The basal serum levels of GH and PRL in lactating cows were not affected either by a long term thyroprotein feeding or withdrawal (Shaw et al., 1975). Furthermore, a parallelism has not been observed in bovine GH, PRL, and TSH releases in responses to milking, parturition, stress such as venipuncture, etc (Johke, unpublished data). Therefore, the physiological significance of TRH in GH and PRL secretions in catıle is not clear at the present time. Nevertheless, the data indicate that TRH may be useful to evaluate the capacity of the bovine pituitary gland to release TSH, GH and PRL at the same time. Further experiments of bovine hormones response to TRH in various physiological conditions are under study. 


\section{Acknowledgements}

The author is indebted to Professor C. H. Li, University of California, U.S.A., for his generous gift of purified bGH. The author is grateful to National Institute of Arthritis, Metabolism, and Digestive Diseases, U.S.A., for providing purified pituitary hormones, to Tanabe Phramaceutical Co. Ltd., Osaka, for their gift of synthetic TRH, and Dr. A. Takagi, Dinabot Radioisotope Laboratory, Tokyo, for supplying $\mathbf{T}_{3}$ RIA kits. The author wishes to thank Dr. S. Honjo, National Institute of Health, Tokyo, for providing facilities and helpfulness for making monkey antisera to bGH and Dr. K. Hodate for his valuable assistance.

\section{References}

Blackwell, R. E. and R. Guillemin (1973). Ann. Rev. Physiol. 35, 357.

Blake, C. A. (1974). Endocrinology 94, 503.

Bourne, R. A. and H. A. Tucker (1975). ibid. 97, 473.

Bowers, C. Y., H. G. Friesen, P. Hwang, H. J.

Guyda and K. Folkers (1971). Biochem. Biophys. Res. Commun. 45, 1033.

Convey, E. M., H. A. Tucker, V. G. Smith and J. Zolman (1973). Endocrinology 92, 471.

Debeljuk, L., A. Arimura, T. Redding and A. V. Schally (1973). Proc. Soc. Exp. Biol. Med. 142, 421.

Fell, L. R., J. K. Findley, I. A. Cumming and J. R. Goding (1973). Endocrinology 93, 487.

Hodate, K. and T. Johke (1977). Proc. 67th Ann. Meeting Jap. Zootech. Sci. Ass. (Abstract in Japanese)

Irie, M. and T. Tsushima (1972). J. Clin. Endocr. Metab. 35, 97.
Jacobs, L. S., P. J. Snyder, R. D. Utiger and W. H. Daughaday (1973). J. Clin. Endocr. Metab. 33, 996.

Johke, T. (1969). Endocrinol. Japon. 16, 581.

Johke, T. (1973). Folia Endocrinol. Japon. 49, 353. (Abstract in Japanese).

Johke, T. (1974). Clin. Endocrinol. 22, 343. (in Japanese)

Johke, T. and K. Hodate (1974). 11th Ann. Meeting of East. Endocr. Soc. (Abstract in Japanese)

Johke, T. (1976). Jap. J. Zootech. Sci. 47. 183. (in Japanese)

Kato, Y., K. Chihara, K. Maeda, S. Ohgo, Y. Okanishi and H. Imura (1975). Endocrinology 96, 114.

Kelly, P. A., K. N. Bedirian, R. D. Baker, and H. G. Friesen (1973). ibid. 92, 1289.

Koprowski, J. A. and H. A. Tucker (1973). ibid. 92, 1480 .

Labella, F. S. and S. R. Vivian (1971). ibid. 88, 787.

Maeda, K., Y. Kato, S. Ohgo, K. Chihara, Y. Yoshimoto, N. Yamaguchi, S. Kuromaru and H. Imura (1975). J. Clin. Endocr. Metab. 40, 501.

McMurtry, J. P. and P. V. Malven (1974). Endocrinology 95, 559.

Mueller, G. P., J. Chen and J. Meites (1973). Proc. Soc. Exp. Biol. Med. 144, 613.

Schams, D. (1972). Horm. Metab. Res. 4, 405.

Shaw, G. H., E. M. Convey, H. A. Tucker, E. P. Reineke, J. W. Thomas and J. J. Bryne (1975). J. Dairy Sci. 58, 703.

Smith, V. G. and E. M. Convey (1975). Proc. Soc. Exp. Biol. Med. 149, 70.

Takahara, H. A., A. Arimura and A. V. Schally (1974). ibid. 146, 831.

Tucker, H. A. and R. P. Wetteman (1976). ibid. 151, 623.

Vines, D. T., H. A. Tucker and E. M. Convey (1976). J. Animal Sci. 42, 681.

Wetteman, R. P. and H. A. Tucker (1974). Proc. Soc. Exp. Biol. Med. 146, 908. 